\title{
Evaluasi Proses Hidrolisis Enzimatis Protein Daging Rusa Sambar (Rusa unicolor) Menggunakan Enzim Pepsin dan Tripsin
}

\author{
Arif Ismanto ${ }^{1}$ \\ ${ }^{1}$ Department of animal science, Agriculture Faculty of Mulawarman University, kampus \\ Gunung Kelua, Jalan Pasir Balengkong, Samarinda 75119. \\ E-mail : arifisamnto9@gmail.com
}

\begin{abstract}
This research conducted to evaluate the hydrolytic process of sambar deer (Rusa unicolor) meat protein as the first step to produced bioactive peptide. The proteolytic enzyme used were pepsin and trypsin. Hydrolysis process evaluated using concentration of soluble protein and Degree of hyrolysis (DH) parameters. Soluble protein concentration determined by Biuret methods. The result showed that concentration of soluble protein $(\mathrm{mg} / \mathrm{ml})$ using Biuret test was $8,33 \pm 0,10$ while after pepsin and trypsin were 8,08 $\pm 0,07$ and 7,89 $\pm 0,12$ respectively. The proximate analysis of Sambar deer meat, water content $73,25 \%$, protein $22,49 \%$, ash $2,35 \%$ and fat was 3,35\%. pH of Sambar deer meat was 7,8 while after pepsin and trypsin were 2,4 and 6,5 respectively. Degree of hydrolysis Sambar meat protein using pepsin was $29 \%$ and using trypsin was $23 \%$.It might conclude that hydrolysis process of Sambar deer meat using pepsin and trypsin was running optimally proved by the increase of soluble protein. Hydrolitic by pepsin was more effective than the trpsin based on $\mathrm{DH}$ value.
\end{abstract}

Keywords : Enzymatic hydrolysis, Pepsin, Tripsin,Sambar deer, Soluble protein

\section{ABSTRAK}

Penelitian ini bertujuan untuk mengevaluasi proses hidrolisis protein daging rusa Sambar (Rusa unicolor) sebagai tahap awal untuk menghasilkan peptida bioaktif. Enzim proteolitik yang digunakan yaitu enzim pepsin dan tripsin. Proses hidrolisis dievaluasi menggunakan parameter protein terlarut, dan Degree of Hydrolysis (DH). Konsentrasi protein terlarut ditentukan dengan metode Biuret. Hasil penelitian menunjukkan bahwa konsentrasi protein terlarut $(\mathrm{mg} / \mathrm{ml})$ menggunakan Biuret sebelum proses hidrolisis adalah $8,33 \pm 0,10$, setelah hidrolisis pepsin adalah sebesar $8,33 \pm 0,10$ dan setelah hidrolisis trypsin adalah 7,89 $\pm 0,12$. Hasil analsis proksimat menunjukkan bahwa daging rusa Sambar memiliki kandungan air $73,25 \%$, protein sebesar $22,49 \%$, abu $2,35 \%$ dan lemak $3,35 \%$. Nilai pH daging rusa Sambar adalah 7,8, setelah hidrolisis pepsin dan tripsin berturut-turut adalah sebesar 2,4 dan 6,5. Degree of Hydrolysis daging rusa Sambar yang telah dihidrolisis oleh pepsin adalah sebesar $29 \%$ dan oleh trypsin adalah sebesar $23 \%$. Dapat disimpulkan bahwa hidrolisis menggunakan pepsin dan trypsin berjalan secara optimal, yang dibuktikan dengan peningkatan kadar protein terlarut. Proses hidrolisis menggunakan pepsin lebih efektif dibandingkan hidrolisis menggunakan trypsin.

Kata kunci: Hidrolisis enzim, Pepsin, Protein, Rusa Sambar, Tripsin

\section{Pendahuluan}

Beberapa tahun terakhir, daging dikembangkan untuk digunakan sebagai sumber peptida fungsional yang dimungkinkan bermanfaat bagi kesehatan (Zang et al., 2010). Peptida diperoleh dari hidrolisis protein daging secara enzimatis. Hidrolisis protein secara enzimatis memiliki beberapa kelebihan yaitu : tidak mengakibatkan kerusakan asamasam amino, peptida rantai pendek yang dihasilkan lebih bervariasi (dipeptida dan tripeptida), dan tingkat kehilangan asam amino esensial lebih rendah. Peptida yang berasal dari proses hidrolisis protein ini biasanya inaktif pada sekuens asam amino protein asal, tetapi bioaktivitas peptida dapat dihasilkan oleh enzim proteolitik pada saat proses pencernaan atau pada saat pengolahan makanan (Ferreira et al., 2007). Hidrolisat 
protein daging sudah digunakan secara luas untuk beberapa hal diantaranya : antihipertensi (Minervini et al., 2003), kekebalan tubuh, antioksidan (Kim et al., 2009) dan antimikrobia dan anti kanker (Jeong et al., 2007; Song et al., 2000).

Rusa sambar (Rusa unicolor) merupakan rusa terbesar untuk daerah tropik dengan sebaran di Indonesia terbatas di pulau Sumatera, Kalimantan dan pulau kecil di sekitar Sumatera (Semiadi, 2001). Rusa sambar memiliki potensi yang cukup baik untuk dikembangkan sebagai ternak terutama untuk pemanfaatan kebutuhan daging (venison). Daging rusa belum banyak dimanfaatkan oleh masyarakat. Hal ini diantaranya disebabkan kurangnya informasi mengenai manfaat daging rusa. Berdasarkan hal tersebut, perlu eksplorasi lebih jauh mengenai potensi daging rusa, baik itu kandungan nutrisi maupun potensinya sebagai sumber bahan yang bermanfaat untuk kesehatan. Informasi yang benar akan meningkatkan perhatian masyarakat dan pemerintah terhadap satwa lokal ini

Penelitian ini dilakukan untuk mengetahui keberhasilan proses hidrolisis protein daging rusa Sambar secara enzimatis menggunakan dua macam enzim protease yaitu enzim pepsin dan enzim tripsin serta dihasilkan hidrolisat protein daging rusa Sambar (Rusa unicolor).

\section{Bahan dan Metode}

Bahan utama digunakan pada penelitian ini adalah daging rusa Sambar. Bahan lainnya yaitu : enzim pepsin dan tripsin untuk hidrolisis protein, aquabides, aquades, $\mathrm{Na} 2 \mathrm{CO} 3, \mathrm{NaOH}$, copper sulfat (CuSO4), $\mathrm{KNa}$ tartrate. Alat-alat pendukung yang digunakan dalam penelitian ini antara lain labu $100 \mathrm{ml}$, labu $250 \mathrm{ml}$, labu $500 \mathrm{ml}$, tabung reaksi, waterbath, vortex,spektrofotometer, mikropipet $100 \mu \mathrm{l}$ sampai $1000 \mu \mathrm{l}$, timbangan digital, rak tabungreaksi, oven, dan eppendorf $0,5 \mathrm{ml}$, sentrifuge.

\subsection{Prosedur Penelitian}

\section{Preparasi Daging Rusa}

Metode preparasi yang digunakan berdasarkan Jang and Lee (2005). Daging rusa disiapkan dan ditimbang sebanyak $100 \mathrm{~g}$, kemudian dipotong menjadi potongan kecilkecil. Daging rusa ditambahkan $200 \mathrm{ml}$ air dan dicampur dengan menggunakan blender kemudian dipanaskan selama 5 menit pada air mendidih. Sampel hasil preparasi daging rusa siap digunakan untuk pengujian selanjutnya.

\section{Digesti Daging Rusa dengan Pepsin}

Preparat daging rusa diatur $\mathrm{pH}$-nya menjadi sekitar 2,0 dengan menambahkan $\mathrm{HCl} 1 \mathrm{~N}$. Enzim Pepsin sebanyak 0,01 g ditambahkan pada preparat daging rusa dan diinkubasi pada suhu $37^{\circ} \mathrm{C}$ selama 2 jam. $\mathrm{pH}$ larutan preparat daging rusa diatur menjadi $\mathrm{pH}$ netral dengan $1 \mathrm{M} \mathrm{NaOH}$, reaksi dihentikan dengan pemanasan pada suhu $95^{\circ} \mathrm{C}$ 
selama 10 menit, diikuti dengan pendinginan pada es. Kemudian preparat daging rusa diambil sebanyak $10 \mathrm{~mL}$ dengan spuit yang dilengkapi dengan filter berukuran diameter 0,45 $\mu \mathrm{m}$ untuk sampel eksperimen.

\section{Digesti Daging Rusa dengan Tripsin}

Preparat daging rusa yang sudah disiapkan sebelumnya ditambahkan tripsin sebanyak $0,01 \mathrm{~g}$. Diinkubasikan selama 2 jam pada suhu $37^{\circ} \mathrm{C}$. Reaksi dihentikan dengan pemanasan pada suhu $95^{\circ} \mathrm{C}$ selama 10 menit, diikuti dengan pendinginan pada es. Selanjutnya diambil preparasi daging rusa sebanyak $10 \mathrm{~mL}$ dengan spuit yang dilengkapi dengan filter berukuran diameter 0,45 $\mu$ m untuk sampel eksperimen.

\section{Analisis Proksimat}

Analisis komposisi kimia daging rusa yang dilakukan meliputi : analisis kadar air, kadar lemak, kadar protein dan kadar abu menurut metode analisis proksimat (AOAC, 1980).

\section{Analisis $\mathrm{pH}$}

Nilai $\mathrm{pH}$ diuji dengan menggunakan elektroda glass $\mathrm{pH}$ meter mengikuti metode yang telah dilakukan oleh Tan et al. (2007). Pengukuran dilakukan sebanyak 3 kali ulangan dan nilainya dirata-rata sebagai nilai $\mathrm{pH}$ produk daging.

\section{Pengujian Konsentrasi Protein Terlarut}

Konsentrasi protein untuk masing-masing fraksi hidrolisis daging rusa, yang terdiri dari : 1) ekstrak daging rusa sebelum didigesti, 2) digesta ekstrak daging rusa menggunakan enzim pepsin, dan 3) digesta ekstrak daging rusa menggunakan enzim tripsin, ditentukan metode Biuret dengan panjang gelombang $540 \mathrm{~nm}$ Owusu-Apenten, 2002). Sebanyak 0,75 gram $\mathrm{CuSO}_{4}{ }^{*} 5 \mathrm{H}_{2} \mathrm{O}$ (copper sulfat) ditambahkan 3 gram $\mathrm{NaKC}_{4} \mathrm{H}_{4} \mathrm{O}_{6}$ (sodium potassium tartrate) dilarutkan dalam $250 \mathrm{ml}$ aquades. Membuat larutan $\mathrm{NaOH}$ (sodium hydroxide) $10 \%$, caranya 15 gram NaOH dilarutkan dalam $150 \mathrm{ml}$ aquades. Selanjutnya larutan $\mathrm{NaOH}$ dicampurkan dengan larutan pertama, tambahkan aquades sampai $500 \mathrm{ml}$. Reagen disimpan dalam tempat gelap, kemudian ditambahkan 0.5 gram KI (potassium iodide). Sampel sebanyak $0.5 \mathrm{ml}$ diambil kemudian ditambahkan dengan reagen biuret $2.5 \mathrm{ml}$, selanjutnya diamkan selama 30 menit, dan diukur absorbansinya pada panjang gelombang $540 \mathrm{~nm}$, selanjutnya dengan larutan blangko ( $0.5 \mathrm{ml}$ aquades ditambahkan $2.5 \mathrm{ml}$ reagen Biuret).

\section{Analisis Degree of Hydrolysis (DH)}

Degree of hydrolisis (DH) ditentukan berdasarkan metode Church, et al. (1983). Diestimasi dengan perubahan konsentrasi peptide dan dihitung dengan rumus sebagai berikut : 
$\% \mathrm{DH}=\left[1-\frac{(\text { konzentrasi peptida pada o jam) }}{(\text { kosentrasi peptida hidrolizat })}\right] \times 100$

\section{Hasil dan Pembahasan}

\section{Analisis proksimat daging Rusa Sambar (Rusa unicolor)}

Berdasarkan Analisis Proksimat yang sudah dilakukan, diketahui bahwa komposisi kimia daging rusa Sambar terlihat seperti pada Tabel 1.

Tabel 1. Hasil analisis proksimat daging rusa sambar (Rusa unicolor) sebelum hidrolisis

\begin{tabular}{clc}
\hline \hline No & Komponen & Persentase \\
\hline 1 & Air & $73,25 \%$ \\
2 & Abu & $2,35 \%$ \\
3 & Lemak & $3,35 \%$ \\
4 & Protein & $22,49 \%$ \\
\hline
\end{tabular}

Daging rusa mempunyai kandungan protein yang tinggi yaitu sekitar 22,49 \%. Kadar protein yang tinggi tersebut memungkinkan penggunaan protein untuk sumber peptida bioaktif. Berdasarkan data skunder diketahui bahwa komposisi asam amino yang terdapat dalam daging rusa adalah 14 macam asam amino (Jamal, et al. 2005). Berdasarkan penelitian yang dilakukan sebelumnya, jenis dan kombinasi asam amino sangat menentukan peptida yang dihasilkan. Kohama et al., (1988) menyatakan bahwa peptida penghambat ACE telah diisolasi dari ekstrak daging tuna. Peptida tersebut adalah pro-thr-his-ile-lys-trp-gly-asp dan mempunyai nilai IC50 sebesar $1 \mu \mathrm{M}$ dan $2 \mu \mathrm{M}$. Arihara et al. (2001) menyatakan bahwa hidrolisat peptida-peptida dari protein otot babi menunjukkan efek antihipertensif, yaitu myopentapeptida met-asn-pro-pro-lys dan ile-thrthr-asn-pro, dan masing-masing menunjukkan aktivitas (IC50) sebesar 945,5 dan 549,0 $\mu \mathrm{M}$, serta enam tripeptida, yaitu met-asn-pro, asn-pro-pro, pro-pro-lys, ile-thr-thr, thr-thrasn, dan thr-asn-pro, yang merupakan bagian dari miopeptida tersebut. Nakashima et al. (2002) menambahkan bahwa empat dari delapan peptida tersebut (met-asn-pro-pro-lys, ile-thr-thr-asn-pro, met-asn-pro, pro-pro-lys) mempunyai efek antihipertensif pada SHR.

\section{Pengujian pH}

Berdasarkan pengujian $\mathrm{pH}$ yang dilakukan didapatkan hasil seperti terlihat pada Tabel 2 berikut :

Tabel 2. Nilai $\mathrm{pH}$ ekstrak daging rusa Sambar (Rusa unicolor) sebelum dan sesudah hidrolisis dengan enzim pepsin dan tripsin

\begin{tabular}{cccc}
\hline \hline \multirow{2}{*}{ No } & Sampel & \multicolumn{2}{c}{$\mathrm{pH}$} \\
\cline { 3 - 4 } & & $\mathrm{pH}$ awal & $\mathrm{pH}$ akhir \\
\hline 1 & Ekstrak daging mentah & - & $7,8 \pm 0,4$ \\
2 & Ekstrak daging hidrolisis Pepsin & 2,00 & $2,4 \pm 0,4$ \\
3 & Ekstrak daging hidrolisis Tripsin & 7,00 & $6,5 \pm 0,7$ \\
\hline
\end{tabular}


Berdasarkan Tabel 2 di atas, terlihat adanya peningkatan nilai $\mathrm{pH}$ pada sampel ekstrak daging hidrolisis pepsin. Nilai $\mathrm{pH}$ ekstrak daging meningkat yaitu dari $\mathrm{pH}$ sekitar 2,00 menjadi 2,4. Pada ekstrak daging hidrolisis tripsin terjadi penurunan nilai $\mathrm{pH}$ dari $\mathrm{pH}$ awal sebesar 7,00 menjadi 6,5. Selama digesti, perubahan nilai $\mathrm{pH}$ kemungkinan disebabkan oleh perbedaan sifat asam amino yang terkandung di dalam bahan. Pada proses hidrolisis ada kemungkinan terjadi degradasi asam amino, apabila asam asam amino yang terdegradasi adalah asam-asam amino yang bersifat asam maka akan terjadi peningkatan $\mathrm{pH}$ demikian sebaliknya.

\section{Protein terlarut}

Kurva standar protein Bovine Serum Albumin (BSA) pada metode Biuret dibuat berdasarkan hasil absorbansi pada panjang gelombang $540 \mathrm{~nm}$. Data hubungan antara konsentrasi dan absorbansi protein BSA terlihat pada Gambar 1.

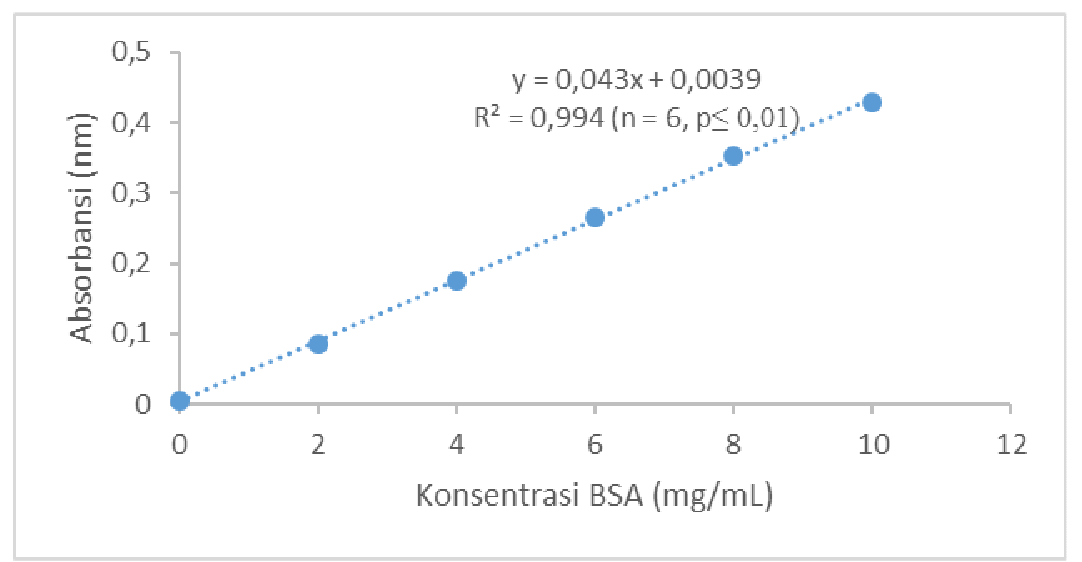

Gambar 1. Kurva Standar Bovine Serum Albumin (BSA) untuk pengujian Biuret.

Kurva standar protein BSA di atas mempunyai nilai $r^{2}$ sebesar 0,994. Nilai tersebut lebih besar $(\geq)$ daripada nilai $r$ tabel $1 \%$ yaitu sebesar 0,9172 . Hal ini merupakan indikasi bahwa kurva standar yang dibuat adalah kurva yang signifikan untuk digunakan sebagai standar penghitungan konsentrasi protein terlarut. Berdasarkan persamaan garis pada grafik yang diperoleh, maka dapat dihitung konsentrasi protein, hasilnya adalah sebagaimana disajikan pada Gambar 2.

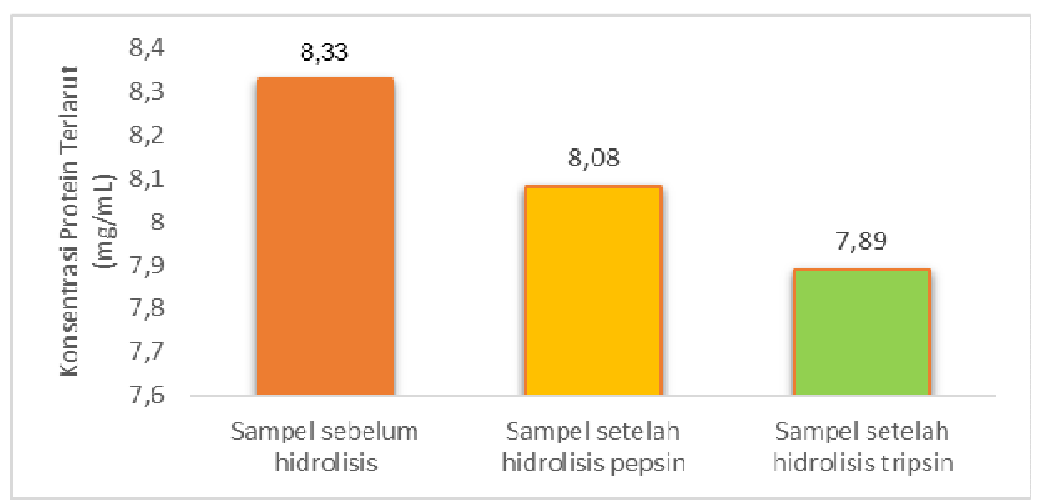

Gambar 2. Hasil pengujian konsentrasi protein terlarut sebelum, sesudah hidrolisis pepsin dan sesudah hidrolisis tripsin $(\mathrm{mg} / \mathrm{mL})$ 
Berdasarkan hasil penghitungan konsentrasi protein terlarut sampel daging rusa sebelum dan sesudah digesti menggunakan enzim pepsin dan tripsin, diperoleh hasil protein terlarutnya berturut-turut adalah 8,33 ; 8,08 dan 7,89 (mg/ml). Sampel setelah proses digesti secara umum, memiliki kandungan protein terlarut yang lebih rendah daripada sampel sebelum digesti. Pepsin hanya memulai proses pencernaan protein, dan menghasilkan 10 sampai $20 \%$ dari pencernaan total protein. Pencernaan protein ini merupakan proses hidrolisis yang terjadi pada ikatan peptida di antara asam-asam amino (Guyton dan Hall, 1997). Pepsin memotong ikatan peptida, terutama ikatan peptida pada sisi terminal C dari residu tirosine, fenilalanin, dan triptofan (Eastwood, 1999). Biuret akan merespon ikatan peptida, hidrolisat mempunyai ikatan peptida yang lebih pendek, sehingga kadar protein terlarutnya menjadi lebih kecil apabila dideteksi dengan uji biuret. Uji biuret akan merespon substansi dengan 2 molekul carbamil $\left(-\mathrm{CONH}_{2}\right)$ yang bergabung secara langsung maupun atom $\mathrm{N}$ atau atom $\mathrm{C}$ secara individual. Selain substansi tersebut, substansi yang mirip, yang mengandung $\mathrm{C}$ pada tempat $-\mathrm{CONH}_{2}$ grup, $\mathrm{CSNH}_{3},-\mathrm{C}(\mathrm{NH}) \mathrm{NH}_{3}$, atau $-\mathrm{CH}_{3} \mathrm{NH}_{3}$ juga akan memberikan respon terhadap uji ini, termasuk juga substansi nonprotein tetapi mengandung grup yang disebutkan di atas juga akan memberikan respon terhadap uji (Oser, 1976). Hidrolisis protein secaraenzimatisoleh pepsin dantripsinakanmemecah protein menjadiasam amino dankomponen lain yang lebihsederhana, selama proses hidrolisisdimungkinkanadaikatanikatanpeptida yang terpecah, sehingga karena berkurangnya substansi-substansi tersebut oleh enzim protease akan menyebabkan menurunnya deteksi oleh biuret.

\section{Analisis Degree of hydrolysis (DH)}

Berdasarkan analisis yang telah dilakukan diketahui Degree of hydrolysis (DH) proses hidrolisis enzymatis protein daging rusa sambar adalah terlihat pada Tabel 3.

Tabel 3. Persentase Nilai DH Ekstrak daging rusa Sambar

\begin{tabular}{|c|c|c|}
\hline No & Sampel & Nilai DH (\%) \\
\hline 1. & $\begin{array}{l}\text { Hidrolisis } \\
\text { pepsin }\end{array}$ & $29 \%$ \\
\hline 2. & Hidrolisis menggunakan tripsin & $23 \%$ \\
\hline
\end{tabular}

Berdasarkan data nilai $\mathrm{DH}$ sampel yang dihidrolisis menggunakan pepsin mempunyai nilai $\mathrm{DH}$ yang lebih kecil daripada nilai $\mathrm{DH}$ sampel yang dihidrolisis menggunakan tripsin. Hal ini kemungkinan disebabkan karena pepsin dan tripsin memiliki respon yang berbeda terhadap asam-asam amino yang dapat dihidrolisis. Penelitian sebelumnya yang dilkukan oleh Cheng et al. (2007) yang melakukan hirolisis enzimatis pada tulang ayam dengan menggunakan enzim pepsin nilai DH nya adalah sebesar $35 \%$ sedangkan hidrolisis tulang ayam dengan menggunakan enzim tripsin adalah sebesar 55 
\%. Perbedaan nilai $\mathrm{DH}$ ini kemungkinan disebabkan perbedaan nilai protein bahan. Protein daging adalah sekitar 20 \% (Koeswara, 2009) dan protein pada Tulang ayam adalah sekitar $23,54 \%$ (Cheng et al., 2008).

\section{Kesimpulan}

Hidrolisis enzimatis daging rusa Sambar (Rusa unicolor) menggunakan enzim pepsin dan dilanjutkan dengan enzim tripsin berjalan dengan optimal. Hal ini dapat dilihat pada parameter nilai protein terlarut. Hidrolisis menggunakan pepsin lebih efektif daripada menggunakan enzim tripsin jika dilihat berdasarkan parameter degree of hydrolysis $(D H)$. Hidrolisat protein daging rusa (Rusa unicolor) mempunyai potensi untuk dikembangkan sebagai sumber peptida yang berfungsi untuk kesehatan.

\section{Ucapan Terima Kasih}

Pada kesempatan ini penulis ingin mengucapkan terima kasih yang sebesarbesarnya kepada Tim PKM Penelitian dan PIMNAS ke 27 di Universitas Diponegoro dari Jurusan Peternakan Fakultas Pertanian Universitas Mulawarman.

\section{Daftar Pustaka}

AOAC. 1980. Official Methods of Analysis, $13^{\text {th }}$ ed. The Association of Official Analytical Chemist, Washington DC.

Arihara K., Y. Nakashima, T. Mukai, S. Ishikawa, and M. Itoh, 2001. Peptide inhibitors for angiotensin I-converting enzyme from enzymatic hydrolysates of porcine skeletal muscle proteins. Meat. Sci 57: 319-324

Cheng, F.Y., Y.T. Liu, T.C. Wan, L.C. Lin, and R. Sakata. 2008. The development of angiotensin I-converting enzyme inhibitor derived from chicken bone protein. J. Anim. Sci. 79: 122-128.

Church, F. C., Swaisgood, H. E., Porter, D. H., \& Catignani, G. L. 1983. Spectrophotometric Assay Using o-Phthaldialdehyde for Determination of Proteolysis in Milk and Isolated Milk Proteins1. Journal of Dairy Science, 66, 12191227. doi:10.3168/jds.S0022-0302(83)81926-2

Eastwood, M. 1999. Principles of Human Nutrition. Aspen Publisher, Inc. Maryland.

Ferreira, I. M. P. L. V. O., Pinho, O., Mota, M. V., Tavares, P., Pereira, a., Gonçalves, M. P., Teixeira, J. a. 2007. Preparation of ingredients containing an ACE-inhibitory peptide by tryptic hydrolysis of whey protein concentrates. International Dairy Journal, 17(5), 481-487. doi:10.1016/j.idairyj.2006.06.023

Guyton dan Hall. 1997. Fisiologi Kedokteran: Edisi 9. Penerbit Buku Kedokteran EGC. Jakarta

Jamal, Y., G. Semiadi dan R.T.P Nugraha. 2005. Kualitas produk ranggah muda rusa sambar tangkaran. Berkala Ilmiah Biologi (UGM) 4: 325 - 336

Jang, A., Lee, M. 2005. Purification and identification of angiotensin converting enzyme inhibitory peptides from beef hydrolysates. Meat Science Journal, 69(4), 653-61.

Jeong, J. B., Jeong, H. J., Park, J. H., Lee, S. H., Lee, J. R., Lee, H. K., et al. 2007. Cancer- preventive peptide lunasin from Solanum nigrum L. inhibits acetylation of 
core histones $\mathrm{H} 3$ and $\mathrm{H} 4$ and phosphorylation of retinoblastoma protein $(\mathrm{Rb})$. Journal of Agricultural Food Chemistry, 55, 10707-10713

Kim, E., Lee, S., Jeon, B., Moon, S., Kim, B., Park, T., Park, P. 2009. Purification and characterisation of antioxidative peptides from enzymatic hydrolysates of venison protein. Food Chemistry, 114(4), 1365-1370. doi:10.1016/j.foodchem.2008.11.035

Koeswara, S. 2009. Pengolahan unggas. E bookpangan.com http :// tekpanunimus.ac.id/wp-content/uploads/2013/07/pengolahan unggas.pdf 18 Oktober 2014

Kohama, Y., Matsumoto, S., Oka, H., Teramoto, T., Okabe, M., \& Mimura, T. (1988). Isolation of angiotensin-converting enzyme inhibitor from tuna muscle. Biochemical and Biophysical Research Communications, 155, 332-337. doi:10.1016/S0006291X(88)81089-1

Minervini, F. F. A., Rizzello, C. G., Fox, P. F., Monnet, V., \& Gobbetti, M. 2003. Angiotensin I-converting-enzyme-inhibitory and antibacterial peptides from Lactobacillus helveticus PR4 proteinase-hydrolyzed caseins of milk from six species. Applied and Environmental Microbiology, 69, 5297-5305.

Nakashima, Y., K. Arihara, A. Sasaki, H. Mio, S. Ishikawa, and M. Itoh, 2002. Antihypertensive activity of peptides derived from porcine skeletal muscle myosin in spontaneously hypertensive rats. J. Food Sci. 67(1): 434-437

Oser, B. L., 1976. Hawk's Physiological Chemistry Fourteen Edition. Tata McGraw-Hill Publishing Company, New York.

Owusu-Apenten, 2002. Food Protein Analysis, Quantitative Effect on Processing. Marcel Dekker, Inc. Switzerlad.

Semiadi G. 2001. Potensi pengembangan peternakan rusa sambar di Kabupaten Paser.Laporan hasil penelitian dan pembinaan Fase 1. Lokakarya Pengembangan Bioteknology Budidaya Rusa Sambar di Kalimantan Timur. Samarinda 6 Nopember 2001.

Song, E. K., kim, H. H., Kim, J. Y., Kang Y. I., Woo, H. J., \& Lee, H. J. 2000. Anticancer activity of hydrophobic peptides from soy proteins. Journal of BioFactors, 12,41514155.

Tan, F.J, F.Y. Liao, Y.J. Jhan, \& Liu DC. 2007. Effect of replacing pork backfat withyams (Dioscoreaalata) on quality characteristics of Chinese sausage. Journal of Food Engineering, 79, 858-863.

Zhang, W., Xiao, S., Samaraweera, H., Lee, E. J., \& Ahn, D. U. 2010. Improving functional value of meat products. Meat science, 86(1), 15-31. doi:10.1016/j.meatsci.2010.04.01 